\title{
Comparison of food habits between native Amur three-lips (Opsariichthys uncirostris uncirostris) and non-native largemouth bass (Micropterus salmoides) in Lake Biwa, Japan
}

\author{
Hiroshi Tsunoda ${ }^{1,2 *}$, Takahiro Urano ${ }^{3}$ and Mitsuru Ohira ${ }^{3}$ \\ 1 Research Center for Wildlife Management, Gifu University, Yanagido 1-1, Gifu, Gifu 501-1193, Japan \\ 2 Center for Environmental Science in Saitama, Kamitanadare 914, Kazo, Saitama 347-0115, Japan \\ ${ }^{3}$ Graduate School of Agriculture, Tokyo University of Agriculture and Technology, Saiwaicho 3-5-8, Fuchu, Tokyo 183-8509, Japan
}

Received 21 April 2015; Accepted 24 August 2015

\begin{abstract}
The Amur three-lips (Opsariichthys uncirostris uncirostris) is an endemic subspecies in Japan and native to the river systems of the Lake Biwa-Yodo River. The population of three-lips in Lake Biwa has decreased, primarily due to habitat degradation and introduction by competitive, non-native predators, such as largemouth bass (Micropterus salmoides). However, the effects of bass introduction on the three-lips are unclear. We investigated the food habits of the three-lips and compared them with those of sympatric nonnative largemouth bass in Lake Biwa. A total of 145 three-lips and 178 largemouth bass were sampled during the summer and fall of 2013. Fish prey, particularly ayu (Plecoglossus altivelis altivelis), was predominant in the three-lips diet, followed by terrestrial insects. Decapods (i.e., prawn and shrimp), ayu and demersal fish (e.g., gobids) composed a substantial proportion of bass diets. No significant dietary overlaps were found between the two predators. Our results suggest that differences in food habits between the two species may result from differences in feeding behavior; the three-lips is a mobile predator that forages mainly on nektonic and suspended food, whereas largemouth bass is an ambush predator that forages on both nektonic and benthic prey. We referred the results of three-lips diets in Lake Biwa in a previous study and suggest that changes in fish fauna, due to introduction by non-native largemouth bass, may have affected prey availability for the three-lips.
\end{abstract}

Key words: Dietary overlap / gut contents / non-native fish / piscivorous fish / prey availability

\section{Introduction}

Fish introductions are one of the most serious threats to freshwater biodiversity (Rahel, 2000, 2002; Clavero and Garcia-Berthou, 2005). Non-native predatory species have often been introduced intentionally into non-indigenous habitats for recreational purposes (Rahel, 2000, 2002; Alcaraz et al., 2005; Eby et al., 2006; Moyle and Marchetti, 2006) and have had a significant effect on the aquatic biota as apex predators in food webs (Jackson et al., 2001; Eby et al., 2006). Invasion of non-native predatory fish not only directly affects species composition and abundance of native animals by predation, but also indirectly alter food web structures and ecosystem processes, e.g., trophic cascades to lower trophic levels (i.e., small benthos and

\footnotetext{
*Corresponding author: tsunoda.hiroshi@gmail.com
}

algae; Eby et al., 2006) and food source competition with native predators (Vander Zanden et al., 1999).

Largemouth bass (Micropterus salmoides Lacepède, 1802) are native to North America but have been introduced and are successfully established in more than 50 countries in Europe, Africa, South America and Asia (Welcomme, 1992). Largemouth bass are predatory, and mainly forage on fish and large crustaceans. Previous researches demonstrated that largemouth bass have negatively affected native species and altered food web structures throughout the globe where they have been introduced (Godinho et al., 1997; Azuma and Motomura, 1998; Weyl and Hecht, 1999; Gratwicke and Marshall, 2001; Jackson, 2002; Maezono and Miyashita, 2003; Yonekura et al., 2004; Maezono et al., 2005; Jang et al., 2006; Tsunoda et al., 2010; Tsunoda and Mitsuo, 2012; Natsumeda et al., 2015). Largemouth bass may also compete with and replace native predatory species 
(e.g., Lorenzoni et al., 2002; Bacheler et al., 2004; Jang et al., 2006).

Largemouth bass has also been introduced into water bodies throughout Japan (Kiryu, 1992). The first introduction of largemouth bass into Lake Biwa, the largest ancient lake of Japan, was recorded in the 1970s (Kiryu, 1992) and irruption of largemouth bass may be the main cause for the decline in Lake Biwa fishes, particularly in littoral cyprinid and gobid species (Maehata, 1993; Nakai and Hamabata, 2002). In Lake Biwa, there is a native predatory fish, the Amur three-lips (Opsariichthys uncirostris Temminck and Schlegel, 1846; family Cyprinidae). The Amur three-lips, sometimes called piscivorous chub, ranges over East Asia in the Korean Peninsula; the Amur River, south of the Yangtze River and Hainan Island in China; and Honshu Island in Japan (Tanaka, 2001). The subspecies, $O . u$. uncirostris, is endemic to Japan and native to the river systems of the Lake Biwa-Yodo River in the Kinki Region and Lake Mikata in Fukui Prefecture on Honshu. The Amur three-lips have been used by local people for traditional food and recreation (Fujioka and Maehata, 2012; Kawanabe et al., 2012). However, declines in the annual catch of three-lips in Lake Biwa have been a concern (see Appendix 1 in electronic-only material), and the Lake Mikata population may be extinct (MOE, 2010). Thus, native three-lips are listed as a vulnerable species in the Red List of the Ministry of the Environment, Japan (MOE, 2010). The main reason for the decline of Lake Biwa three-lips is thought to be habitat degradation by alterations in the littoral zone and river improvements (MOE, 2010; Imamura, 2014). However, the introduction of competitive, non-native predatory fish species, such as largemouth bass, is another possible reason (MOE, 2010). One study conducted a DNA analysis of bass feces and found proportionally higher consumption of three-lips juveniles by largemouth bass (Sugiura and Taguchi, 2011); however, food resource competition between these two species has not been reported. Previous studies showed Amur three-lips and largemouth bass have similar diets (i.e., mainly consumed fish preys) in allopatric environments in Japan (three-lips, Tanaka, 1964; Kurita et al., 2008; Sano, 2012; largemouth bass, Azuma and Motomura, 1998; Yodo and Kimura, 1998; Kuge et al., 2004; Tsunoda et al., 2009; Sugiura and Taguchi, 2011; Taguchi et al., 2014) and a stable isotope analysis indicated a similarity in those species trophic levels in Lake Biwa (Okuda et al., 2012). Therefore, largemouth bass could negatively affect the three-lips as a potential competitor for food resources, while no study has directly observed and compared the diets of the two species.

The present study is the first report of a food habit comparison between the Amur three-lips and largemouth bass in Lake Biwa. We compared food habits and estimated diet overlap of the two species by analyzing their gut contents. We also compared Amur three-lips food habits data to other food habits data collected before the introduction of largemouth bass in Lake Biwa to determine potential shift that may have occurred in the presence of a new predator.

\section{Materials and methods}

\section{Study area}

Lake Biwa $\left(34^{\circ} 58^{\prime}-35^{\circ} 30^{\prime} \mathrm{N}, 135^{\circ} 51^{\prime}-136^{\circ} 16^{\prime} \mathrm{E}\right)$ is located in Shiga Prefecture, the central part of Honshu, Japan (Fig. 1). Lake Biwa is the largest lake in Japan (ca. $670 \mathrm{~km}^{2}$ and $103 \mathrm{~m}$ in maximum depth) and is one of the most ancient lakes in the world, as it was formed about 4.5 million years ago (Kawanabe et al., 2012). Numerous endemic species and a relatively high biodiversity are found in Lake Biwa; 46 indigenous fish species and subspecies occur there, of which 17 species/subspecies are endemic to the lake (Maehata, 2012).

\section{Field surveys}

We sampled fish in the littoral zone ( $<5 \mathrm{~m}$ depth) between summer and early autumn (mid-July to early October 2013) as this period had the greatest potential for resource overlap between the two species (Sunaga, 1980; Nakamura, 1992). Six sampling sites were established in the estuarine areas of rivers that flow into Lake Biwa (Fig. 1), which have mud, sand and/or gravel substrates and are partially covered with emergent (e.g., Phragmites australis Trin. ex Steud.) and submergent aquatic plants (e.g., Potamogeton maackianus A. Been and Elodea nuttallii (Planch.) H. St. John). Fish were caught by lure angling throughout the study period, and cast nets $(4.1-\mathrm{m}$ diameter with $9.5-\mathrm{mm}$ mesh and $4.7-\mathrm{m}$ diameter with $12.5-\mathrm{mm}$ mesh) were used in July and early August. Angling or cast netting for either species was not prohibited in Lake Biwa during the study season. However, because catch of several fish species (e.g., ayu, Plecoglossus altivelis altivelis Temminck and Schlegel, 1846) were restricted from mid-August to November by local fishery regulation, we sampled only by angling to avoiding bycatch of the restricted species. Fish were sampled by five researchers for $2 \mathrm{~h}$ at each site. The sampled fishes were killed immediately. The gut was injected with $10 \%$ formalin to fix the contents, and the fish were held on ice in situ. All samples were transported to the laboratory and frozen at $-20{ }^{\circ} \mathrm{C}$ until the dietary analysis.

\section{Gut content analysis}

Standard length (SL, $\mathrm{mm}$ ) and body wet weight (BW, g) of each individual were recorded before the gut was removed. Gut contents were examined by sight or using a microscope $(10 \times)$ and identified to the level of order, family, or species, if possible. The total wet weight $(0.001 \mathrm{~g})$ of each prey item in the gut was recorded, except nonfood material, such as plants, sand, gravel or plastic fishing lures.

For describing the proportion of a prey item in gut contents, we used the percent frequency of occurrence 

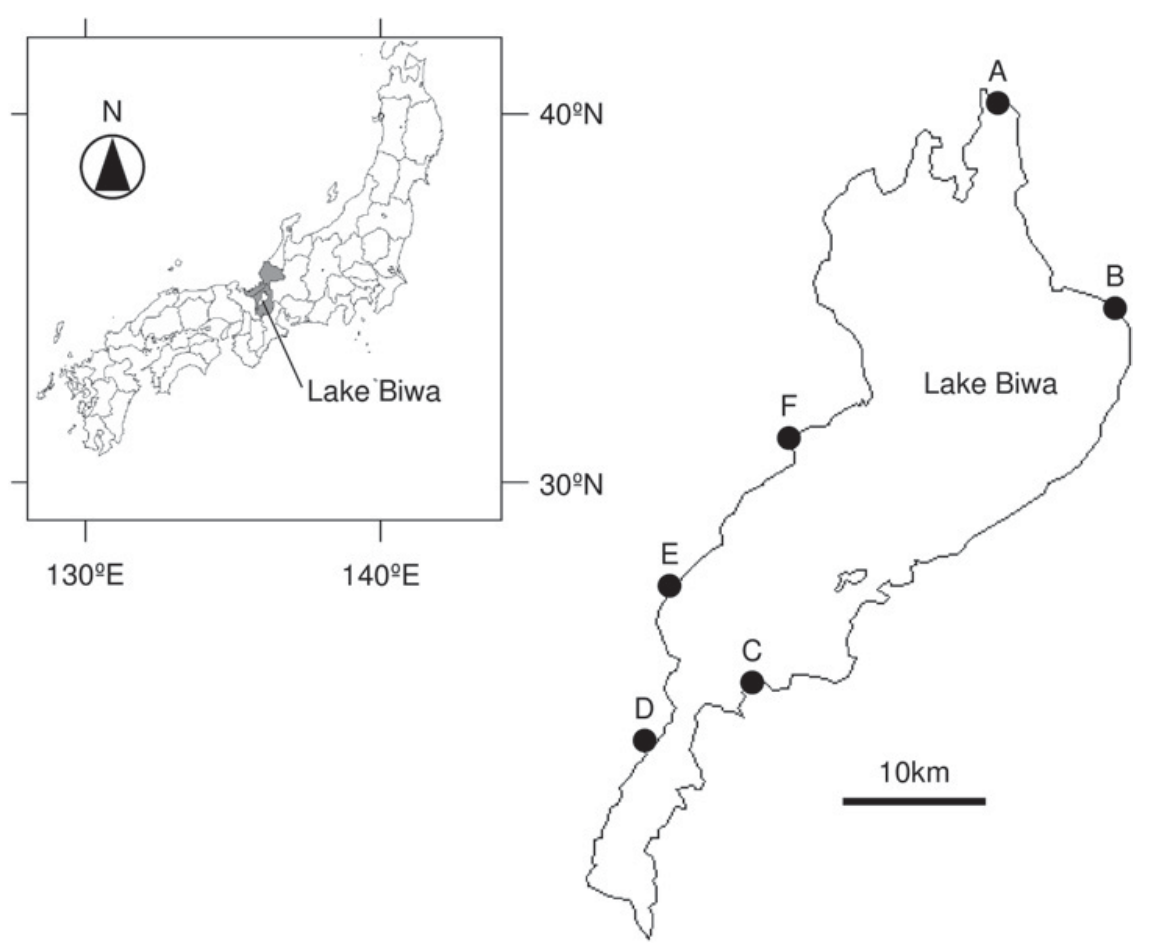

Fig. 1. Lake Biwa and sampling site locations (solid circles; A-F).

$(\% \mathrm{~F})$ and percent by prey weight $(\% \mathrm{~W})$. We calculated $\% \mathrm{~F}$ and $\% \mathrm{~W}$ for each prey item as follows:

$$
\begin{aligned}
\% \mathrm{~F} i= & \text { (number of guts containing a prey item } i / \\
& \text { number of guts with any contents }) \times 100 ;
\end{aligned}
$$

and

$$
\begin{aligned}
\% \mathrm{~W} i= & (\text { total weight of a prey item } i / \\
& \text { total weight of all prey items }) \times 100 \text {. }
\end{aligned}
$$

For the food habits analysis, we divided the samples into three body-size classes (small, $<120 \mathrm{~mm} \mathrm{SL}$; medium, $120-180 \mathrm{~mm} \mathrm{SL}$; and large, >180 mm SL) to determine ontogenetic changes in food habits for both species. We used the age class size categories for the Amur three-lips, as reported previously for Lake Biwa (Tanaka, 1964), to assess potential competitive effects of largemouth bass on Amur three-lips at different age classes. Both the Amur three-lips (Tanaka, 1964; Sano, 2012) and largemouth bass (Olson, 1996; Garcia-Berthou, 2002) show ontogenetic shifts in diet and change to piscivory at juvenile stage: $1+$ year-classed fish (ca. $>70 \mathrm{~mm} \mathrm{SL}$ ) of the three-lips starts to prey on fishes (Tanaka, 1964), while yearlings of largemouth bass start piscivory with $30-50 \mathrm{~mm}$ of body length (Azuma and Motomura, 1998; Yasuno et al., 2012; Taguchi et al., 2014), indicating that two species may be potentially competitive after $1+$ year. The sampled fishes were included within the size-classes in potentially piscivorous for both species (i.e., $>70 \mathrm{~mm}$ SL for three-lips and $>50 \mathrm{~mm}$ for largemouth bass; see Fig. 2). For the analysis, we combined all monthly data because of short study period (i.e., 3 months) and small sample size (see Appendix 2).

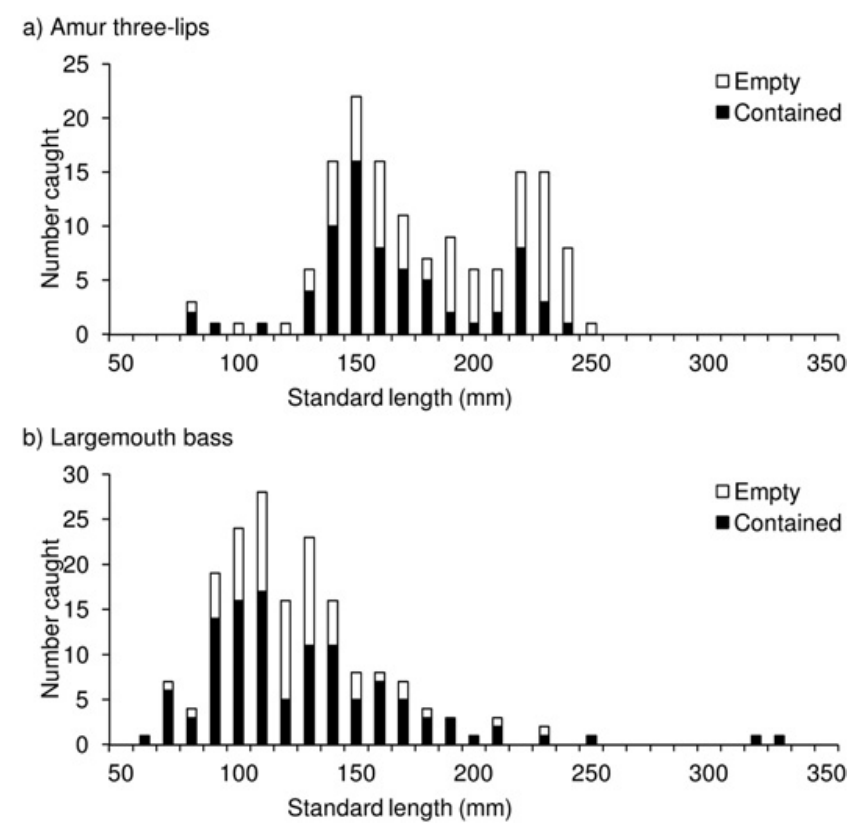

Fig. 2. Size distributions of sampled native Amur three-lips (Opsariichthys uncirostris uncirostris (a); and non-native largemouth bass (Micropterus salmoides (b) in Lake Biwa.

\section{Analysis of dietary overlap}

Dietary overlap was determined using Schoener's index ( $\alpha$; Schoener, 1970) and the null-model test (Winemiller and Pianka, 1990). Schoener's index is the most appropriate and commonly used method to assess overlap of 

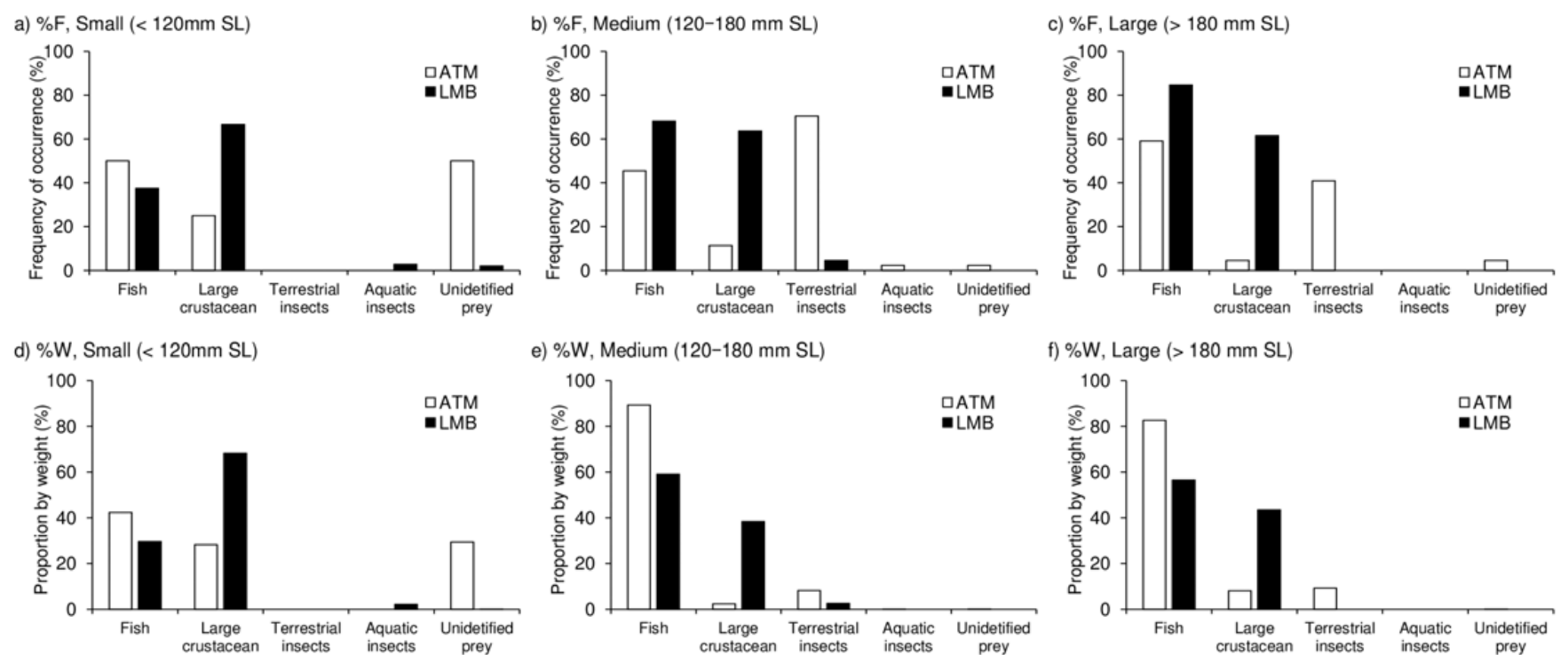

Fig. 3. Food habits comparisons in different size-classes between native Amur three-lips (Opsariichthys uncirostris uncirostris; ATL) and non-native largemouth bass (Micropterus salmoides; LMB) in Lake Biwa. $\% \mathrm{~F}$ and \% $\%$ represent the percent frequency of occurrence and the percent by prey weight, respectively.

food habits (Wallace, 1981). The index was calculated as follows:

$$
\alpha=1-0.5\left(\sum|\mathrm{ATL} i-\mathrm{LMB} i|\right),
$$

where $\mathrm{ATL} i$ and $\mathrm{LMB} i$ represent the $\% \mathrm{~F}$ and $\% \mathrm{~W}$ of the prey category $i$ in the diets of the Amur three-lips and largemouth bass, respectively. We categorized the prey items into five groups, including fish, large crustaceans, terrestrial insects, aquatic insects and unidentified prey. Dietary overlap was analyzed for each size class. The nullmodel test is a statistical approach to determine whether niche overlap is significant (Winemiller and Pianka, 1990). The statistical significance of dietary overlap was determined by comparing the observed value of $\alpha$ to the simulated value from the null distribution. The null distribution was created from 1000 randomizations of data provided using the "scrambled-zeros" randomization algorithm (Winemiller and Pianka, 1990). A significant dietary overlap between two species is detected when the observed value is $>95 \%$ of the simulated at $P<0.05$ (Winemiller and Pianka, 1990). We used EcoSim ver. 7.0 for the null-model test analysis (Gotelli and Entsminger, 2001).

\section{Results}

A total of 145 Amur three-lips and 178 largemouth bass were sampled, of which $52 \%(n=75)$ and $36 \%$ $(n=64)$ had empty guts, respectively. Length of the sampled fishes ranged from 80 to $252 \mathrm{~mm}$ SL for three-lips and from 68 to $332 \mathrm{~mm}$ SL for largemouth bass, respectively (Fig. 2). The ratio of empty guts of three-lips increased with increasing body size (Fig. 2 and Appendix 2). For largemouth bass, however, the ratio of empty guts was the highest in medium size class and the lowest in the large size class (Appendix 2).

Unidentified fish were the predominant prey of smallsized three-lips, comprising $50 \%$ of the $\% \mathrm{~F}$ and $42 \%$ of the $\% \mathrm{~W}$ of the diet, although the sample size was small $(n=4$; Fig. 3). In contrast, decapods (i.e., prawn and shrimp) were the predominant prey for small-sized largemouth bass, followed by fish prey (mostly unidentified species but including ayu and some gobid species; Fig. 3 and Appendix 2).

For medium-sized three-lips, terrestrial insects were the predominant prey on the basis of occurrence, followed by fish (Fig. 3), while fish was the predominant prey on the basis of weight (Fig. 3). For medium-sized largemouth bass, fish and large crustaceans were the most dominant on the basis of occurrence (Fig. 3). On the other hand, fish was more predominant than large crustaceans in the bass diet by weight (Fig. 3). For both species, ayu was the most predominant prey in diets on the basis of weight (see Appendix 2).

Fish were the predominant prey for large three-lips by frequency and weight (Fig. 3). The majority of the fish prey was unidentified species on the basis of occurrence $(\% \mathrm{~F}=45 \%)$ but ayu comprised $13 \%$. In addition, ayu was the most predominant prey item by weight $(\% \mathrm{~W}=42 \%$; see Appendix 2). Terrestrial insects were secondary in importance by frequency and weight. Fish was more predominant than large crustaceans in the diet of large-sized bass on the basis of occurrence (Fig. 3), while fish and large crustaceans were equally dominant by weight (Fig. 3). For largemouth bass, ayu was the most predominant prey in this class $(\% \mathrm{~F}=31 \%$ and $\% \mathrm{~W}=42 \%$, respectively; see Appendix 2).

Dietary overlap indices between Amur three-lips and largemouth bass were estimated $0.46-0.58$ on the 
Table 1. The dietary overlap index between native Amur three-lips (Opsariichthys uncirostris uncirostris) and non-native largemouth bass (Micropterus salmoides) in Lake Biwa.

\begin{tabular}{|c|c|c|c|c|}
\hline \multirow[b]{2}{*}{ Body-size class } & \multirow[b]{2}{*}{ Diet index* } & \multicolumn{2}{|c|}{ Schoener's index } & \multirow{2}{*}{$\frac{\text { Null-model test }}{P}$} \\
\hline & & Observed & Simulated (SD) & \\
\hline \multirow[t]{2}{*}{$<120 \mathrm{~mm} \mathrm{SL}^{* *}$} & $\% \mathrm{~F}$ & 0.563 & $0.412(0.021)$ & 0.290 \\
\hline & $\% \mathrm{~W}$ & 0.579 & $0.395(0.017)$ & 0.204 \\
\hline \multirow[t]{2}{*}{$120-180 \mathrm{~mm} \mathrm{SL}$} & $\% \mathrm{~F}$ & 0.464 & $0.414(0.028)$ & 0.425 \\
\hline & $\% \mathrm{~W}$ & 0.641 & $0.249(0.028)$ & 0.060 \\
\hline \multirow[t]{2}{*}{$>180 \mathrm{~mm} \mathrm{SL}$} & $\% \mathrm{~F}$ & 0.583 & $0.378(0.030)$ & 0.102 \\
\hline & $\% \mathrm{~W}$ & 0.646 & $0.263(0.026)$ & 0.097 \\
\hline
\end{tabular}

$* \% \mathrm{~F}$, the percentage frequency of occurrence; $\% \mathrm{~W}$, the percentage of prey weight.

**Standard length.

basis of occurrence (i.e., $\% \mathrm{~F}$ ) and $0.58-0.65$ on the basis of weight (i.e., \% $\mathrm{W}$ ). Based on the null-model test, however, there were no significant dietary overlaps between three-lips and largemouth bass within each size class (Table 1).

\section{Discussion}

\section{Potential resource competition}

Our results show that the food habits of the Amur three-lips were different from sympatric, non-native largemouth bass, although both species mainly preyed on fish preys. These dietary differences between the two species may be a result of differences in feeding behavior because three-lips are predominately mobile predators (Tanaka, 2001), whereas largemouth bass switch between ambush and mobile predation (Savino and Stein, 1982). This was reflected in the results of gut contents analysis, as three-lips mainly foraged on nektonic minnows, such as ayu, and suspended terrestrial insects, whereas largemouth bass preyed on benthic prey, such as large crustaceans and gobids relatively larger amounts and more frequently. Similar results were observed in Lake Kawaguchi, central Japan, where non-indigenous Amur three-lips forage for fish and terrestrial insects, and sympatric non-native largemouth bass mainly forage for prawns (Urano et al., 2014).

As the three-lips and largemouth bass have similar diets (i.e., mainly forage on ayu, cypinids and gobids) in allopatric environments in Japan (three-lips, Tanaka, 1964; Kurita et al., 2008; Sano, 2012; largemouth bass, Azuma and Motomura, 1998; Yodo and Kimura, 1998; Kuge et al., 2004; Tsunoda et al., 2009; Sugiura and Taguchi, 2011; Taguchi et al., 2014), their food niches could overlap. Thus, food resource competition between the two species has been a concern where they are sympatric (MOE, 2010). However, our results show no significant dietary overlap between three-lips and largemouth bass in Lake Biwa, indicating little direct competition for food resources between the two species. Food resource partitioning has often been observed among sympatric piscivorous fish (Winemiller, 1989;
Liao et al., 2002; Wheeler and Allen, 2003; Pelicice and Agostinho, 2005; Wuellner et al., 2010; Walker et al., 2013) and it can reduce direct interspecific competition for food (Winemiller, 1989). In addition, Ross (1986) suggested that food resource partitioning may be more important in structuring fish assemblages than habitat segregation. Resource partitioning between native and non-native species may contribute to the persistence of the native species after invasion by a non-native competitor. Bacheler et al. (2004) suggested that local extinction of the native bigmouth sleeper (Gobiomorus dormitor Lacepède, 1800) in some Puerto Rican reservoirs may have been caused by competition with non-native largemouth bass because the food niche overlapped significantly between the two species. In contrast, native lake trout (Salvelinus namaycush Walbaum, 1792) in some Canadian lakes coexist with competitive, non-native smallmouth bass (Micropterus dolomieu Lacepède, 1802) and rock bass (Ambloplites rupestris Rafinesque, 1817), due to a shift from foraging on littoral fish (e.g., cyprinids) to foraging on pelagic fish (e.g., cisco, Coregonus sp. or alewife, Alosa pseudoharengus Wilson, 1811) or zooplankton (Vander Zanden et al., 1999; Lepak et al., 2006; Morbey et al., 2007). Thus, the food differences between the two species may enable three-lips to coexist with competitive largemouth bass in Lake Biwa.

\section{Changes in the diet of Lake Biwa three-lips after introduction by largemouth bass}

The prey of Amur three-lips in Lake Biwa before introduction of largemouth bass (ca. 50 years ago) included ayu, gobid (Rhinogobius sp.), and cyprinid (e.g., Gnathopogon caerulescens Sauvage, 1883) species between summer to autumn (Tanaka, 1964). The sampling sites (i.e., littoral zone) and the methods of gut content analysis (i.e., the percent frequency of occurrence and the percent by weight) were common between the two studies, while the sampling method of the present study (angling and cast netting) was different from the previous one (beach seines; Tanaka, 1964). Thus, we can compare the results of the gut content analysis between the two studies. Although we found that all body-size classes of the three-lips remained 
mainly piscivorous, prey composition differed from that reported previously (Tanaka, 1964), particularly in the decline/disappearance of gobids and cyprinids in the diet of the three-lips.

We speculate that food habits changes in the three-lips was mainly caused by changes in the Lake Biwa fish fauna over the last five decades due to human activities, as human activities have greatly altered the lake environment and affected the biodiversity in Lake Biwa (Kawanabe et al., 2012). The number and abundance of some indigenous Lake Biwa fish species have declined because of overfishing (1969-1991), alteration/destruction of reed zones and littoral areas, i.e., lacustrine fish habitat (by the "Lake Biwa Comprehensive Development Program", 1972-1997), and invasion by non-native fish species (since the late 1980s) (Maehata, 2012; Nakai, 2012). Indeed, a declining trend in the total annual catch (i.e., an indicator of abundance; Nakai, 1999) of some species has been reported, e.g., Carassius sp., G. caerulescens and Gymnogobius isaza Tanaka, 1916 (see Appendix 1 in electronic-only material), and these species were found to be mainly preyed on by three-lips in a previous study (Tanaka, 1964).

It also suggested that irruption of largemouth bass may be the main cause for the decline in Lake Biwa fishes, particularly in littoral cyprinid and gobid species (Nakai and Hamabata, 2002) because those species are susceptible to the predatory impact of bass (Jackson et al., 2001; Maezono and Miyashita, 2003; Yonekura et al., 2004; Tsunoda et al., 2010; Tsunoda and Mitsuo, 2012). In fact, 12 cyprinid species have disappeared, and the populations of eight cyprinid and one gobid species have declined for about 10 years after irruption of largemouth bass in the southern part of Lake Biwa (Maehata, 1993). We speculate that changes in the fish fauna due to irruption of the bass may affect prey availability, resulting in dietary changes by the three-lips before and after the Lake Biwa bass introduction. This assumption is consistent with the results of some studies reporting that reductions in fish prey abundance by the predatory impact of invading smallmouth bass and/or rock bass altered the food habits of native lake trout and facilitated dietary shifts to predominately zooplankton in several Canadian lakes (Vander Zanden et al., 1999; Lepak et al., 2006). Further study using stable isotope analysis is recommended to help clarify the dietary shift of three-lips due to the effects of largemouth bass introduction on prey availability in Lake Biwa. The stable isotope analysis method is appropriate to help understand food web changes and interactions among populations over long periods (Vander Zanden et al., 1999; Galster et al., 2012; Guzzo et al., 2013). In addition, trophic niche shifts in native predator caused by invasion of non-native competitors also affected fitness or fitnessrelated factors (e.g., fecundity, growth and survival) of the native species (Vander Zanden et al., 1999), indicating that negative (indirect) effects of the non-native competitor were persistent. We also suggest further study and monitoring on fitness or the related factors of the threelips in Lake Biwa.

\section{Conclusion}

Our results indicate little food competition between native Amur three-lips and non-native largemouth bass in Lake Biwa but these differences may be related to a shift in food habits of Amur three-lips after largemouth bass were introduced. Further study is recommended to understand the mechanism of the effects of reduction in the prey fish availability on the three-lips, such as archival specimens analyzed with a stable isotope (e.g., Okuda et al., 2012). In addition, previous studies suggest that reducing suitable prey by introducing competitive predators can affect body condition, growth and reproduction of native predators (Vander Zanden et al., 1999; Lepak et al., 2006). Ontogenetic dietary shifts from planktivory to piscivory are important for growth of young three-lips, and gobids (e.g., Rhinogobius sp.) were the most predominant food for them before the Lake Biwa bass invasion (Tanaka, 1964). As mentioned above, gobids are susceptible to bass invasion (e.g., Maezono and Miyashita, 2003; Tsunoda et al., 2010), and our results indicated a reduction in gobids in the diet of young three-lips, compared with that reported previously (Tanaka, 1964). We suggest that both direct predation on juveniles and reduction in preferable prey availability by largemouth bass on growth and survival of young three-lips need to be evaluated in a further study. The Lake Biwa three-lips is not only an endangered species but also an important fishery resource for local traditional food culture (Fujioka and Maehata, 2012). Therefore, future studies will contribute to the planning and development of countermeasures for competitive non-native bass to conserve the three-lips population as a sustainable resource.

Acknowledgements. We are grateful to students of Tokyo University of Agriculture and Technology for their field assistance. We also thank Dr Munemitsu Akasaka for fruitful comments on a draft of this manuscript and Dr Masahiro Nakajima for his cooperation. This study was partly supported by SUMASUI Nature Conservation Foundation 2013 (to UT) and JSPS KAKENHI Grant Number 25740049 (to HT).

\section{References}

Alcaraz C., Vila-Gispert A. and Garcia-Berthou E., 2005. Profiling invasive fish species: the importance of phylogeny and human use. Divers. Distrib., 11, 289-298.

Azuma M. and Motomura Y., 1998. Feeding habits of largemouth bass in a non-native environment: the case of a small lake with bluegill in Japan. Environ. Biol. Fish., 52, 379-389.

Bacheler N.M., Neal J.W. and Noble R.L., 2004. Diet overlap between native bigmouth sleepers (Gobiomorus dormitor) and introduced predatory fishes in a Puerto Rico reservoir. Ecol. Freshw. Fish, 13, 111-118.

Clavero M. and Garcia-Berthou E., 2005. Invasive species are a leading cause of animal extinctions. Trends Ecol. Evol., 20, 110 . 
Eby L.A., Roach W.J., Crowder L.B. and Stanford J.A., 2006. Effects of stocking-up freshwater food webs. Trends Ecol. Evol., 21, 576-584.

Fujioka Y. and Maehata M., 2012. Various fishing methods developed in and around Lake Biwa. In: Kawanabe H., Nishino M. and Maehata M. (eds.), Lake Biwa: Interactions between Nature and People, Springer, Tokyo, 317-326.

Galster B.J., Wuellner M.R. and Graeb B.D.S., 2012. Walleye Sander vitreus and smallmouth bass Micropterus dolomieu interactions: an historic stable-isotpe analysis approach. J. Fish Biol., 81, 135-147.

Garcia-Berthou E., 2002. Ontogenetic diet shifts and interrupted piscivory in introduced largemouth bass (Micropterus salmoides). Int. Rev. Hydrobiol., 87, 353-363.

Godinho F.N., Ferreira M.T. and Cortes R.V. 1997. The environmental basis of diet variation in pumpkinseed sunfish, Lepomis gibbonus, and largemouth bass, Micropterus salmoides, along an Iberian river basin. Environ. Biol. Fish., 50, 105-115.

Gotelli N.J. and Entsminger G.L., 2001. EcoSim: null models software for ecology Version 7.0. Acquired Intelligence Inc. and Kesey-Bear. Accessed online at 26 March 2014, http:// homepages.together.net/ gentsmin/ecosim.htm.

Gratwicke B. and Marshall B.E., 2001. The relationship between the exotic predators Micopterus salmoides and Serranochromis robustus and native stream fishes in Zimbabwe. J. Fish Biol., 58, 68-75.

Guzzo M.M., Haffner G.D., Legler N.D., Rush S.A. and Fisk A.T., 2013. Fifty years later: trophic ecology and niche overlap of a native and non-indigenous fish species in the western basin of Lake Erie. Biol. Invasions, 15, 1695-1711.

Imamura A., 2014. A detailed assessment of the distribution of Opsariichthys uncirostris uncirostris along the shoreline of Lake Biwa (in Japanese with English summary). Jpn. J. Conserv. Ecol., 19, 151-158.

Jackson D.A., 2002. Ecological effects of Micropterus introductions: the dark side of black bass. In: Phillip D.P. and Ridgway M.S. (eds.), Black Bass: Ecology, Conservation, and Management, American Fisheries Society, Bethesda, MD, 221-232.

Jackson D.A., Peres-Neto P.R. and Olden J.D., 2001. What controls who is where in freshwater fish communities - the roles of biotic, abiotic, and spatial factors. Can. J. Fish. Aquat. Sci., 58, 157-170.

Jang M.H., Joo G.J. and Lucas M.C., 2006. Diet of introduced largemouth bass in Korean rivers and potential interactions with native fishes. Ecol. Freshw. Fish, 15, 315-320.

Kawanabe H., Nishino M. and Maehata M., 2012. Lake Biwa: Interactions between Nature and People, Springer, Tokyo, $744 \mathrm{p}$.

Kiryu T., 1992. Distribution and habitats (in Japanese). In: National Federation of Inlandwater Cooperatives (ed.), The Review of Exotic Largemouth Bass Micropterus salmoides and Bluegill Lepomis macrochirus, Fisheries Agency, Tokyo, 20-27.

Kuge T., Nobusawa K. and Maita M., 2004. Abundance and feeding habits of largemouth bass Micropterus salmoides in Haruna Lake, Gunma prefecture, Japan (in Japanese with English summary). Suisanzoshoku, 52, 73-80.

Kurita Y., Nakajima J., Kaneto J. and Onikura N., 2008. Analysis of the gut contents of the internal exotic fish species
Opsariichthys uncirostris uncirostris in the Futatsugawa River, Kyushu Island, Japan. J. Fac. Agric. Kyushu Univ., 53, 429-433.

Lepak J.M., Kraft C.E. and Weidel B.C., 2006. Rapid food web recovery in response to removal of an introduced apex predator. Can. J. Fish. Aquat. Sci., 63, 569-575.

Liao H., Pierce C.L. and Larscheid J.G., 2002. Diet dynamics of the adult piscivorous fish community in Spirit Lake, Iowa, USA. Ecol. Freshw. Fish, 11, 178-189.

Lorenzoni M., Corboli M., Dorr A.J.M., Giovinazzo G., Selvi S. and Mearelli M., 2002. Diets of Micropterus salmoies Lac. and Esox lucius L. in Lake Trasimeno (Umbria, Italy) and their diet overlap. Bull. Fr. Pêche Piscic., 365/366, 537-547.

Maehata M., 1993. Trend in fish fauna around the Biwako Bunkakan (the south basin) (in Japanese). Ann. Rep. Biwako Bunkakan, 11, 43-49.

Maehata M., 2012. Characteristics of the ichthyofauna of Lake Biwa, with special reference to its long-term changes. In: Kawanabe H., Nishino M. and Maehata M., (eds.), Lake Biwa: Interactions between Nature and People, Springer, Tokyo, 119-122.

Maezono Y. and Miyashita T., 2003. Community-level impacts induced by introduced largemouth bass and bluegill in farm ponds in Japan. Biol. Conserv., 109, 111-121.

Maezono Y., Kobayashi R., Kusahara M. and Miyashita T., 2005. Direct and indirect effects of exotic bass and bluegill on exotic and native organisms in farm ponds. Ecol. Appl., 15, 638-650.

Ministry of the Environment (MOE), 2010. Appendix of the Red List Revised Edition: Brackish and Freshwater Fishes (in Japanese). Ministry of the Environment, Tokyo, 78 p.

Morbey Y.E., Vascotto K. and Shuter B.J., 2007. Dynamics of piscivory by lake trout following a smallmouth bass invasion: a historical reconstruction. Trans. Am. Fish. Soc., 136, $477-483$.

Moyle P.B. and Marchetti M.P., 2006. Predicting invasion success: freshwater fishes in California as a model. Bioscience, 56, 515-524.

Nakai K., 1999. Recent faunal changes in Lake Biwa, with particular reference to the bass fishing boom in Japan. In: Kawanabe H., Coulter G.W. and Roosevelt A.C. (eds.), Ancient Lakes: their Cultural and Biological Diversity, Kenobi Productions, Ghent, 189-202.

Nakai K., 2012. Regulations and control of invasive nonindigenous species. In: Kawanabe H., Nishino M. and Maehata M. (eds.), Lake Biwa: Interactions between Nature and People, Springer, Tokyo, 477-484.

Nakai K. and Hamabata E., 2002. Lake Biwa (in Japanese). In: Ecological Society of Japan (ed.), Hanbook of Alien Species in Japan, Chijin-Shokan, Tokyo, 265-268.

Nakamura M., 1992. Interspecific interactions (in Japanese). In: National Federation of Inlandwater Cooperatives (ed.), The Review of Exotic Largemouth Bass Micropterus salmoides and Bluegill Lepomis macrochirus, Fisheries Agency, Tokyo, 62-69.

Natsumeda T., Takamura N., Nakagawa M., Kadono Y., Tanaka T. and Mitsuhashi H. 2015. Environmental and biotic characteristics to discriminate farm ponds with and without exotic largemouth bass and bluegill in western Japan. Limnology, 16, 139-148. 
Okuda N., Takeyama T., Komiya T., Kato Y., Okuzaki Y., Karube J., Sakai Y., Hori M., Tayasu I. and Nagata T., 2012. A food web and its long-term dynamics in Lake Biwa: a stable isotope approach. In: Kawanabe H., Nishino M. and Maehata M. (eds.), Lake Biwa: Interactions between Nature and People, Springer, Tokyo, 205-210.

Olson M.H., 1996. Ontogenetic niche shifts in largemouth bass: variability and consequences for first year growth. Ecology, 77, 179-190.

Pelicice F.M. and Agostinho A.A., 2005. Feeding ecology of fishes associated with Egeria spp. patches in a tropical reservoir, Brazil. Ecol. Freshw. Fish, 15, 10-19.

Rahel F.J., 2000. Homogenization of fish faunas across the United States. Science, 288, 854-856.

Rahel F.J., 2002. Homogenization of freshwater faunas. Аnпu. Rev. Ecol. Syst., 33, 291-315.

Ross S.T., 1986. Resource partitioning in fish assemblages: a review of field studies. Copeia, 2, 352-388.

Sano J., 2012. Ecological study on non-indigenous piscivorous chub invaded into Fukuoka Prefecture (in Japanese). Bull. Fukuoka Fish. Mar. Technol. Res. Cent., 22, 49-55.

Savino J.F. and Stein R.A., 1982. Predatory-prey interaction between largemouth bass and bluegill as influenced by simulated, submerged vegetation. Trans. Am. Fish. Soc., $111,255-266$.

Schoener T.W., 1970. Non-synchronous spatial overlap of lizards in patchy habitats. Ecology, 51, 408-418.

Sugiura S. and Taguchi T., 2011. Estimating the feeding habits of largemouth bass and bluegill around Noda Lake, a satellite lake of Lake Biwa, based on stomach contents and fecal DNA (in Japanese with English summary). Nippon Suisan Gakkaishi, 78, 43-53.

Sunaga T., 1980. Piscivorous chub (in Japanese). In: Kawai T., Kawanabe H. and Mizuno N. (eds.), Freshwater Organisms of Japan, Tokai University Press, Tokyo, 30-36.

Taguchi T., Miura Y., Kruger D. and Sugiura S., 2014. Utilizing stomach content and faecal DNA analysis techniques to assess the feeding behaviour of largemouth bass Micropterus salmoides and bluegill Lepomis macrochirus. J. Fish Biol., 84, 1271-1288.

Tanaka S., 1964. The food and growth of "Hasu", Opsariichthys uncirostris (T. \& S.) in the Lake Biwa (in Japanese with English summary). Physiol. Ecol. Jpn, 12, $106-114$.

Tanaka S., 2001. Piscivorous chub (in Japanese). In: Kawanabe H., Mizuno N. and Hosoya K. (eds.), Freshwater Fishes of Japan, Revised edition, Yamatokeikoku-sha, Tokyo, $250-255$.

Tsunoda H. and Mitsuo Y., 2012. Multiple effects of exotic largemouth bass (Micropterus salmoides) and environmental factors on species richness and composition of pond-dwelling fishes. Aquat. Living Resour., 25, 163-171.

Tsunoda H., Senga Y. and Watanabe M., 2009. Feeding habits of largemouth bass in Lake Saiko and Shojiko, Yamanashi
Prefecture (in Japanese with English summary). Wildl. Conserv. Jpn, 12, 1-11.

Tsunoda H., Mitsuo Y., Ohira M., Doi M. and Senga Y., 2010. Change of fish fauna in ponds after eradication of invasive piscivorous largemouth bass, Micropterus salmoides, in north-eastern Japan. Aquat. Cons. Mar. Freshw. Ecosyst., 20, 710-716.

Urano T., Tsunoda H. and Senga Y., 2014. Feeding habits of two sympatric alien predatory fishes, Opsariichthys uncirostris uncirostris and Micropterus salmoides, in Lake Kawaguchi (in Japanese with English summary). Biol. Inland Waters, 29, 39-49.

Vander Zanden M.J., Casselman J.M. and Rasmussen J.B., 1999. Stable isotope evidence for the food web consequences of species invasions in lakes. Nature, 401, 464-467.

Walker R.H., Kluender E.R., Inebnit T.E. and Adams S.R., 2013. Differences in diet and feeding ecology of similar-sized spotted (Lepisosteus oculatus) and shortnose (Lepisosteus platostomus) gars during flooding of a south-eastern US river. Ecol. Freshw. Fish, 22, 617-625.

Wallace Jr, R.K., 1981. An assessment of diet-overlap indexes. Trans. Am. Fish. Soc., 110, 72-76.

Welcomme R.L., 1992. A history of international introductions of inland aquatic species. ICES J. Mar. Sci., 194, 3-14.

Weyl O.L.F. and Hecht T., 1999. A successful population of largemouth bass, Micropterus salmoides, in subtropical lake in Mozambique. Environ. Biol. Fish., 54, 53-66.

Wheeler A.P. and Allen M.S., 2003. Habitat and diet partitioning between shoal bass and largemouth bass in the Chipola River, Florida. Trans. Am. Fish. Soc., 132, 438-449.

Winemiller K.O., 1989. Ontogenetic diet shifts and resource partitioning among piscivorous fishes in the Venezuelan ilanos. Environ. Biol. Fish., 26, 177-199.

Winemiller K.O. and Pianka E.R., 1990. Organization in natural assemblages of desert lizards and tropical fishes. Ecol. Monogr., 60, 27-55.

Wuellner M.R., Chipps S.R., Willis D.W. and Adams Jr, W.E., 2010. Interactions between walleyes and smallmouth bass in a Missouri River reservoir with consideration of the influence of temperature and prey. N. Am. J. Fish. Manage., 30, 445-463.

Yasuno N., Chiba Y., Shindo K., Fujimoto Y., Shimada T., Shikano S. and Kikuchi E., 2012. Size-dependent ontogenetic diet shifts to piscivory documented from stable isotope analyses in an introduced population of largemouth bass. Environ. Biol. Fish., 93, 255-266.

Yodo T. and Kimura S., 1998. Feeding habits of largemouth bass Micropterus salmoides in lakes Shorenji and Nishinoko, central Japan (in Japanese with English summary). Nippon Suisan Gakkaishi, 64, 26-38.

Yonekura R., Kita M. and Yuma M., 2004. Species diversity in native fish community in Japan: comparison between noninvaded and invaded ponds by exotic fish. Ichthyol. Res., 51, 176-179. 